
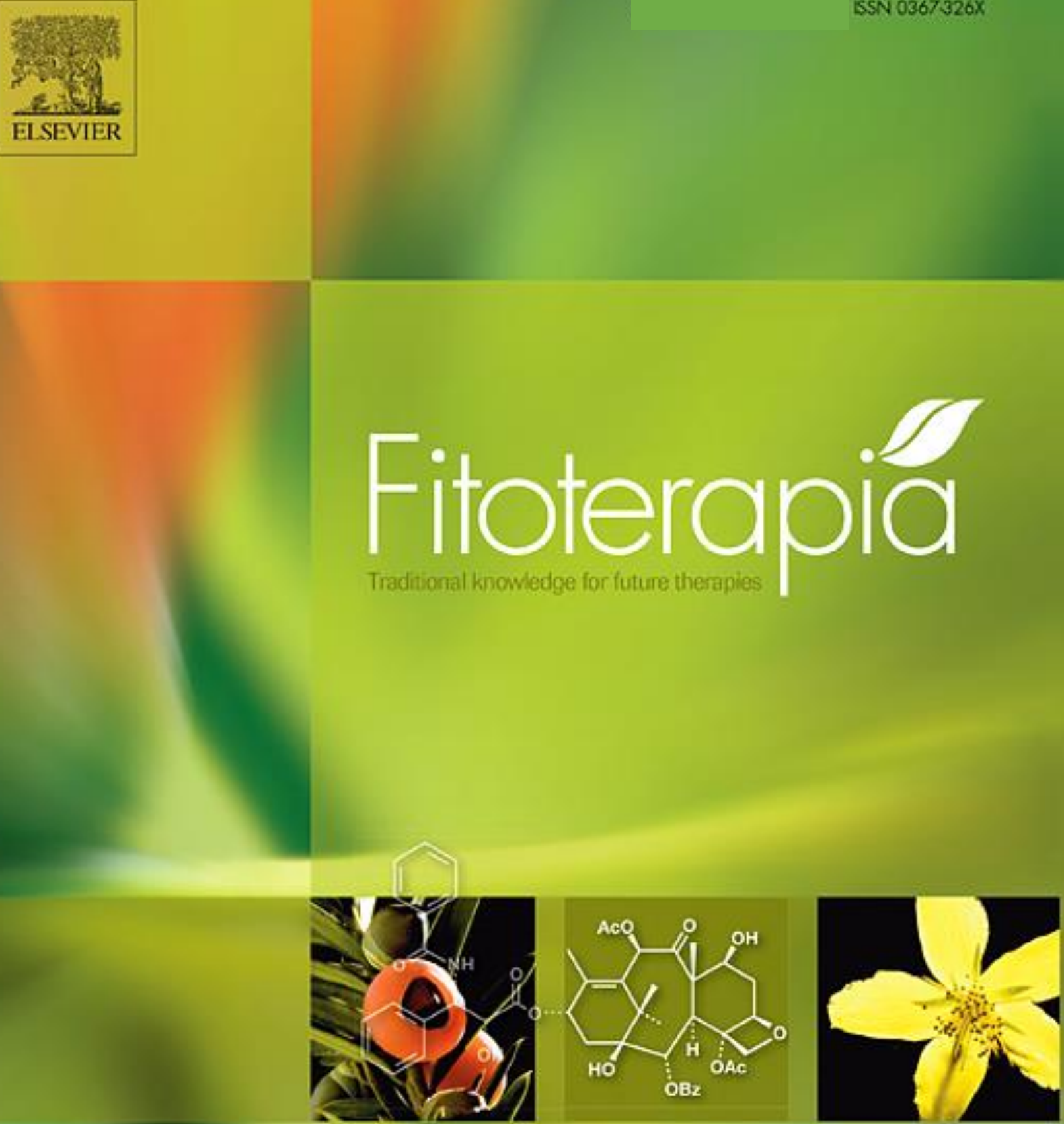

Founded by Indenailf 1924 
Fitoterapia Vol. 83, No. 5, 2012

\section{Contents}

\section{REVIEW}

Phyto-chemical and pharmacological applications of Berberis aristata

Dipti Potdar*, R.R. Hirwani, Sivakami Dhulap

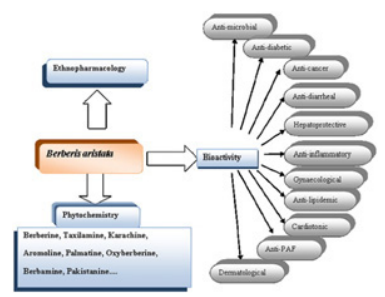

\section{FULL PAPERS}

Polyprenols from the needles of Taxus chinensis var. mairei

pp 831-837

Jinhui Yu, Yanbin Wang, Hua Qian*, Yunpeng Zhao, Bentong Liu, Chengxin Fu**

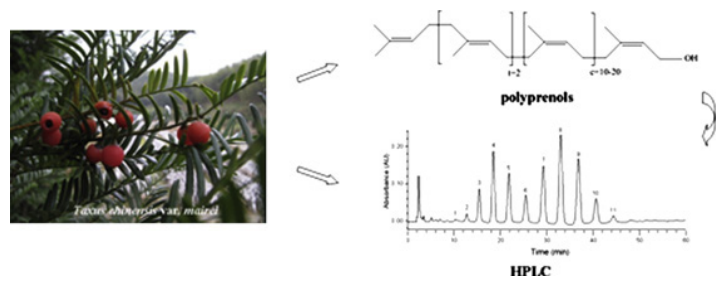

Trichosanthin down-regulates Notch signaling and inhibits proliferation of the nasopharyngeal carcinoma cell line CNE2 in vitro

Fenye Liu, Bing Wang, Zhixue Wang, Shudong Yu*

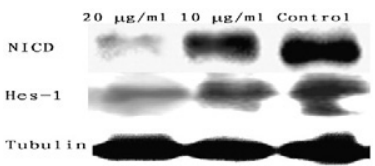


Triterpene saponins from the roots of Dipsacus asper and their protective effects against the $A \beta_{25-35}$ induced cytotoxicity in PC12 cells

De Ji, Yue Wu, Bin Zhang, Chun-Feng Zhang*, Zhong-Lin Yang*
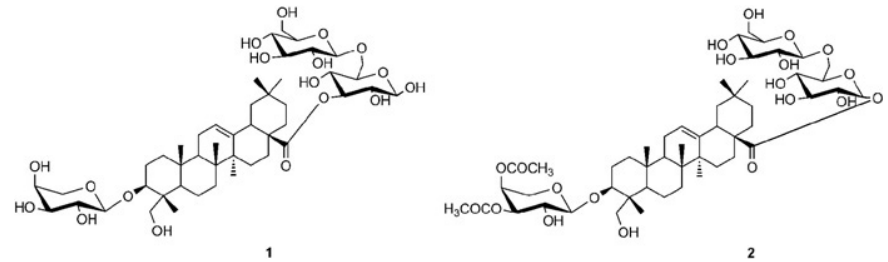

The effect of curcin from Jatropha curcas on apoptosis of mouse sarcoma-180 cells

Qi Zhao, Wenguo Wang, Yuehua Wang, Ying Xu, Fang Chen*

The mouse sarcoma-180 cells undergoing apoptosis induced by curcin.

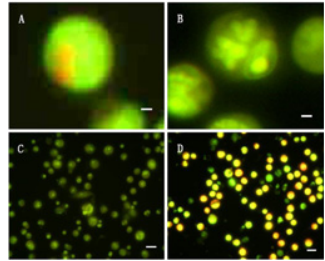

Anti-inflammatory and analgesic potential of a novel steroidal derivative from Bryophyllum pinnatum

pp 853-858 Muhammad Afzal, Gaurav Gupta, Imran Kazmi*, Mahfoozur Rahman, Obaid Afzal, Jahangir Alam, Khalidur Rahman Hakeem, Mohammad Pravez, Ritu Gupta, Firoz Anwar**<smiles>C=C(/C=C/[C@H](CC)C(C)C)[C@H]1CCC2C3CCC4=CC(=O)CCC4(C)[C@H]3CC[C@@]21C</smiles>

\section{Labdane-type diterpenes and flavones from Dodonaea viscosa}

Hippolyte Kamdem Wabo, Philippe Chabert, Pierre Tane*, Olivier Noté, Michel Feussi Tala, Jean Peluso, Christian Muller, Haruhisa Kikuchi, Yoshiteru Oshima, Annelise Lobstein

A new labdane diterpenoid, 2,18-dihydroxylabda-7,13(E)-dien-15-oic acid (1), and a new flavone, 5,7-dihydroxy-3,6,4'-trimethoxy-3'-(4-hydroxy-3-methylbut-2-enyl)flavone (2) with two known labdane diterpenes and three flavones were isolated from Dodonaea viscosa. Their structures were determined by extensive analysis of spectroscopic data and by comparison with literature data. The anti-inflammatory activity of some of the compounds was evaluated with a flow cytometry TNF- $\alpha$ secretion assay on human Thp-1 cell line.

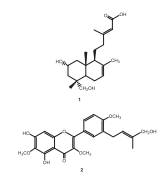




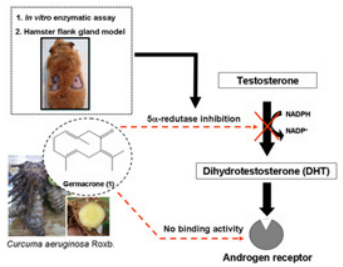

Anti-Helicobacter pylori activity of Terminalia macroptera root

Olga Silva*, Sílvia Viegas, Cristina de Mello-Sampayo, Maria João P. Costa, Rita Serrano, José Cabrita, Elsa T. Gomes

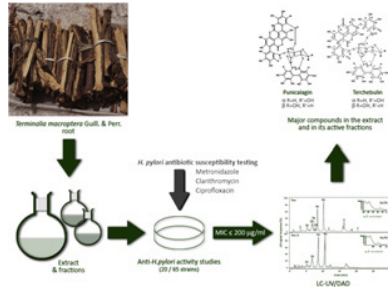

Betula pendula leaves: Polyphenolic characterization and potential innovative use in skin whitening products

M.P. Germanò, F. Cacciola, P. Donato, P. Dugo, G. Certo, V. D'Angelo, L. Mondello, A. Rapisarda*

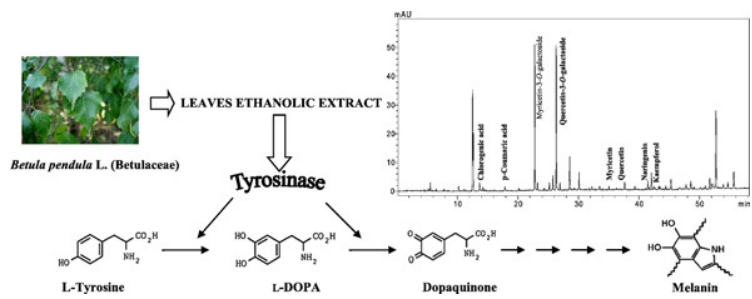

Phenolics from Leontopodium leontopodioides inhibiting nitric oxide production

pp 883-887

Xin Li, Jian-Guang Luo, Xiao-Bing Wang, Jun Luo, Jun-Song Wang, Ling-Yi Kong*

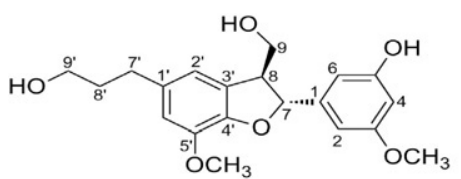

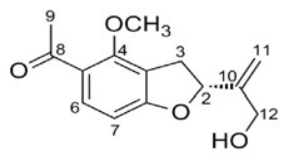


Evaluation of aqueous and ethanolic extracts of saffron, Crocus sativus L., and its constituents, safranal and crocin in allodynia and hyperalgesia induced by chronic constriction injury model of neuropathic pain in rats

Bahareh Amin, Hossein Hosseinzadeh*

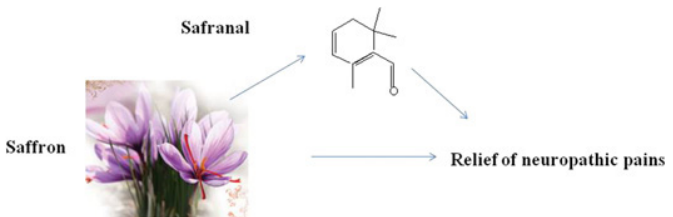

Anti-neuroinflammatory constituents from Polygala tricornis Gagnep Jun Li, Ke-Wu Zeng, She-Po Shi, Yong Jiang, Peng-Fei Tu*
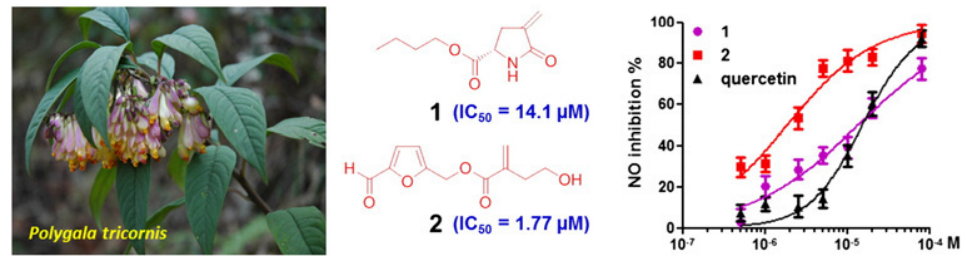

A new protolimonoid from Capuronianthus mahafalensis

pp 901-906

Torgils Fossen, Philippe Rasoanaivo*, Christian Sambany Manjovelo, Fanja Hanitriniala Raharinjato, Sviatlana Yahorava, Aleh Yahorau, Jarl Erik Sylvester Wikberg

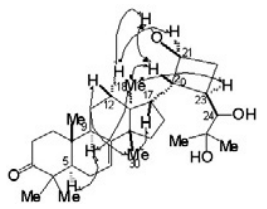

Kujigamberol, a new dinorlabdane diterpenoid isolated from 85 million years old Kuji amber using a biotechnological assay

Ken-ichi Kimura*, Yuki Minamikawa, Yukiko Ogasawara, Jun Yoshida, Kei-ichi Saitoh, Hisao Shinden, Yue Qi Ye, Shunya Takahashi, Tokichi Miyakawa, Hiroyuki Koshino

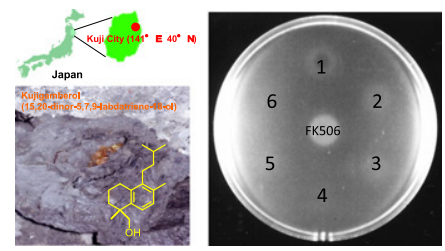




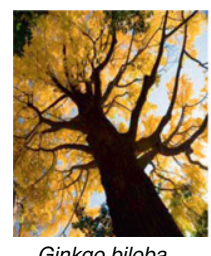

Ginkgo biloba

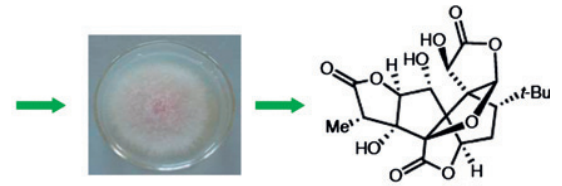

Fusarium oxysporum

Ginkgolide B

Bioactivity-guided isolation of antiproliferative compounds from Centaurea jacea $\mathrm{L}$.

pp 921-925

Peter Forgo, István Zupkó, Judit Molnár, Andrea Vasas, György Dombi, Judit Hohmann*
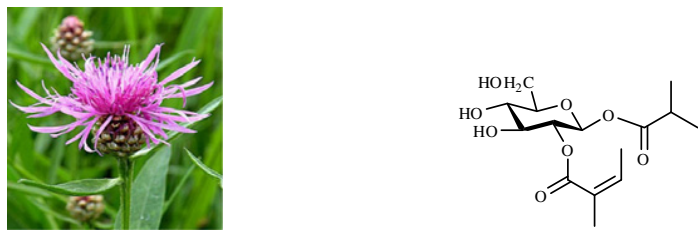

$1 \beta$-isobutanoyl-2-angeloyl-glucose

Cycloartane triterpenoids from the stems of Schisandra glaucescens and their bioactivity

pp 926-931

Juan Zou, Jing Jiang, Yan-Yan Diao, Li-Bin Yang, Jin Huang, Hong-Lin Li, Xue Du, Wei-Lie Xiao*, Jian-Xin Pu, Han-Dong Sun*

Five new cycloartane triterpenoids, together with two known compounds, were isolated from the stems of Schisandra glaucescens.

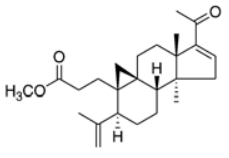

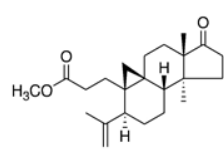

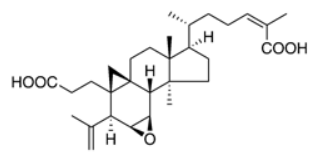

4

Phytochemical and antimicrobial investigations of stilbenoids and flavonoids isolated from three

pp 932-939 species of Combretaceae

David R. Katerere*, Alexander I. Gray, Robert J. Nash, Roger D. Waigh<smiles>COc1ccc(CC(O)c2cc(OC)c(OC)c(OC)c2)cc1O</smiles> 
Potential effects of lignan-enriched flaxseed powder on bodyweight, visceral fat, lipid profile,

pp 940-945 and blood pressure in rats

Jae B. Park*, Manuel T. Velasquez

Potential health effects of lignan-enriched flaxseed powder with 35\% secoisolariciresinol diglucoside (SDG) on bodyweight, visceral fat, lipid profile, adipokines, and blood pressure in rats.

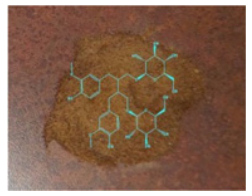

Molecular analysis of the genus Asparagus based on matK sequences and its application to identify $A$. racemosus, a medicinally phytoestrogenic species Teerawat Boonsom, Neti Waranuch, Kornkanok Ingkaninan, Jessada Denduangboripant, Suchada Sukrong*

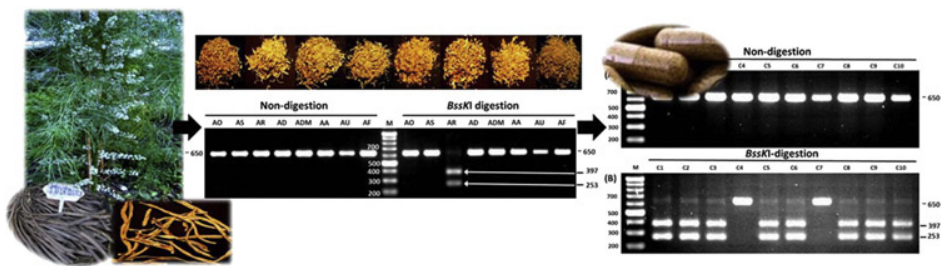

Transdermal behaviors comparisons among Evodia rutaecarpa extracts with different purity of evodiamine and rutaecarpine and the effect of topical formulation in vivo Fei Chen, Su Li, Dai Li, Jin-Song Ding*

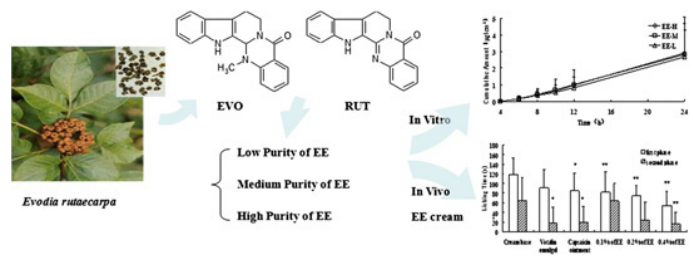

Bioactivity-guided fractionation of the lipoxygenase and cyclooxygenase inhibiting constituents from Chisocheton polyandrus Merr

Kit Yee Chan, Khalit Mohamad, Audrey J.A. Ooi, Zamrie Imiyabir, Lip Yong Chung*
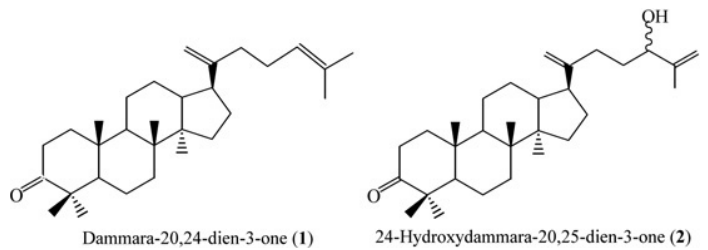

pp 960-966 


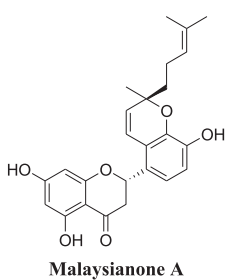

Steroids with inhibitory activity against the prostate cancer cells and chemical diversity of marine alga Tydemania expeditionis

Jian-Long Zhang, Hai-Yan Tian, Juan Li, Lu Jin, Cheng Luo, Wen-Cai Ye, Ren-Wang Jiang*

Steroids with inhibitory activities against the prostate cancer cells were isolated from Tydemania expeditionis. Molecular docking revealed the important role of carbonyl group in the interactions with androgen receptor.

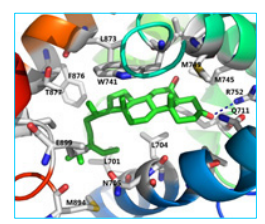

Cited in: Beilstein Database, BIOSIS/Biological Abstracts, CAB Abstracts, Cambridge Scientific Abstracts, Chemical Abstracts Service, CINAHL Elsevier BIOBASE/Current Advances in Biological Sciences, EMBASE/Excerpta Medica, EMBiology PUBMED/ MEDLINE/Index Medicus, Natural Products Update/RSC, International Pharmaceutical Abstracts, Science Citation Index Expanded. Also covered in the abstract and citation database SciVerse Scopus ${ }^{\circledR}$. Full text available on SciVerse ScienceDirect ${ }^{\circledR}$

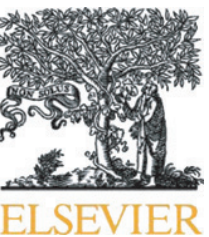

ISSN 0367-326X 


\title{
Flavonoids with antiplasmodial and cytotoxic activities of Macaranga triloba
}

\author{
Ishak Zakaria ${ }^{a}$, Norizan Ahmat ${ }^{\mathrm{a}, *}$, Faridahanim M. Jaafar ${ }^{\mathrm{a}}$, Aty Widyawaruyanti ${ }^{\mathrm{b}}$ \\ a Faculty of Applied Sciences, Universiti Teknologi MARA, 40450 Shah Alam, Selangor, Malaysia \\ b Department of Phytochemistry \& Pharmacognosy, Faculty of Pharmacy, University of Airlangga, 60286 Surabaya, Indonesia
}

\section{A R T I C L E I N F O}

\section{Article history:}

Received 15 November 2011

Received in revised form 20 April 2012

Accepted 21 April 2012

Available online 27 April 2012

\section{Keywords:}

Euphorbiaceae

Macaranga triloba

Flavonoids

Malaysianone A

Antiplasmodial

Cytotoxic

\begin{abstract}
A B S T R A C T
A new flavanone derivative, malaysianone $A(1)$, four prenylated flavanones, 6-prenyl-3'methoxyeriodictyol (2), nymphaeol B (3), nymphaeol $C(4)$ and 6-farnesyl-3 ${ }^{\prime}, 4^{\prime}, 5,7-$ tetrahydroxyflavanone (5), and two coumarins, 5,7-dihydroxycoumarin (6) and scopoletin (7), were isolated from the dichloromethane extract of the inflorescences of Macaranga triloba. The structures of these compounds were elucidated based on spectroscopic methods including nuclear magnetic resonance (NMR-1D and 2D), UV, IR and mass spectrometry. The cytotoxic activity of the compounds was tested against several cell lines, with $\mathbf{5}$ inhibiting very strongly the growth of HeLa and $\mathrm{HL}-60$ cells $\left(\mathrm{IC}_{50}: 1.3 \mu \mathrm{g} / \mathrm{ml}\right.$ and $3.3 \mu \mathrm{g} / \mathrm{ml}$, respectively). Compound 5 also showed strong antiplasmodial activity $\left(\mathrm{IC}_{50}: 0.06 \mu \mathrm{M}\right)$.
\end{abstract}

(c) 2012 Elsevier B.V. All rights reserved.

\section{Introduction}

Macaranga triloba, locally known as "Mahang merah", is a tree endemic to Southeast Asia found at forest margins. Its water extract was used as pain relief for stomach trouble in Java [1]. Previous investigation on the chemistry and pharmacology of this genus showed that its crude extracts displayed an interesting bioactivity profile, possessing various bioactivities including antioxidant $[2,3]$, cyclooxygenase-I and II-inhibitory [4], antibacterial [5], antitumor and antimicrobial [6], and cytotoxic effects [7-9]. The genus Macaranga, one of the largest genera of the Euphorbiaceae family has approximately 280 species [10]. This genus is known for a wide range of mutualistic associations with ants, ranging from facultative to strictly obligate relationships $[11,12]$. In Malaysia, there are approximately 40 species, growing mostly in secondary forests [13]. Macaranga has been reported as a plant rich in prenylated flavonoids, especially geranyl flavonoids [14-17]. This paper reports the structure elucidation of $\mathbf{1}$ and the bioactivities of the isolated flavonoids from the inflorescences of $M$. triloba.

\footnotetext{
* Corresponding author. Tel.: +60 355444619 ; fax: +60 355444562 . E-mail address: noriz118@salam.uitm.edu.my (N. Ahmat).
}

\section{Experimental}

\subsection{General experimental procedures}

${ }^{1} \mathrm{H}$ and ${ }^{13} \mathrm{C}$ NMR were recorded in $\mathrm{CDCl}_{3}$ on a Bruker 300 Ultrashield NMR spectrometer measured at 300 and $75 \mathrm{MHz}$, respectively. Chemical shifts $(\delta)$ are reported in ppm and coupling constants $(J)$ are reported in $\mathrm{Hz}$. CD spectra were recorded on a JASCO J-720WI spectropolarimeter. HRESI-MS were obtained with an Agilent TOFLC/MS G6224A mass spectrometer. Infrared (IR) spectra were recorded on a Perkin Elmer Spectrum One FTIR spectrometer. Ultraviolet (UV) spectra were recorded on Shimadzu UV-vis 160i spectrophotometer. The following adsorbents were used for purification: VLC used Silica gel 60, 70-230 mesh ASTM (Merck cat no. 1.07747), radial chromatography used Si-gel $60 \mathrm{PF}_{254}$ (Merck cat. no. 1.07749) and TLC analysis with Merck Kieselgel 60 F254 $0.25 \mathrm{~mm}$ (cat. no. 1.05554). Distilled technical and analytical grade solvents were used in this study.

\subsection{Plant material}

The inflorescences of $M$. triloba were collected from Pasir Raja, Hulu Terengganu, Malaysia and identified by Dr. Shamsul 
Khamis, Institute of Bioscience, Universiti Putra Malaysia. A voucher specimen (UiTM17/09) was deposited at the Herbarium of Universiti Teknologi MARA, Malaysia.

\subsection{Extraction and isolation}

The inflorescences $(1.5 \mathrm{~kg}$ ) of $M$. triloba were air dried, ground and soaked successively with $n$-hexane, dichloromethane and methanol ( $3 \times 16 \mathrm{~L}, 24 \mathrm{~h}$ each). The dichloromethane extract $(44.41 \mathrm{~g})$, a dark brown gum, was subjected to vacuum liquid chromatography (VLC) on silica gel using a gradient elution system of $n$-hexane/EtOAc 10:0, 9:1, 8:2, 7:3 $6: 4,5: 5,4: 6,3: 7,2: 8,1: 9$ and $0: 10$. Twenty-five fractions were obtained and spotted on TLC using the same solvent system. Similar TLC profiles were grouped to yield 6 fractions $\left(F_{1}-F_{6}\right)$. Fraction $\mathrm{F}_{3}$ was subjected to column chromatography (CC) using gradient elution system of $n$-hexane/ $\mathrm{CHCl}_{3} 1: 9$ and $n$ hexane/EtOAC 10:0, 9:1, 8:2, 7:3, 6:4, 5:5, 4:6, 3:7, 2:8, 1:9 and $0: 10$ to yield 47 fractions, which were pooled based on TLC profiling, to yield 15 fractions $\left(F 1_{1}-F 1_{15}\right)$. Fraction $F 1_{3}$ was subjected to preparative thin-layer chromatography (PTLC) to obtain $6(5.0 \mathrm{mg})$ using solvent system $\mathrm{CH}_{2} \mathrm{Cl}_{2}$ /acetone 95:5 ( $1 \mathrm{~mm}$ thickness). Fraction $\mathrm{F}_{5}$ was subjected to medium pressure liquid chromatography (MPLC) using gradient elution system of $\mathrm{H}_{2} \mathrm{O} / \mathrm{MeCN} 8: 2,7: 3,6: 4,5: 5,4: 6$ and $3: 7$ to yield 27 fractions $\left(F 2_{1}-F 2_{27}\right)$. Fractions $\left(F 2_{1}-F 2_{6}\right)$ were combined and subjected to radial chromatography $(\mathrm{RC})$ to yield $2(21.1 \mathrm{mg})$ using $\mathrm{CHCl}_{3}$ /acetone 9:1 (2 mm thickness). Fraction $\mathrm{F}_{6}$ was further chromatographed on reverse-phased column chromatography (RPCC) to yield 26 fractions $\left(\mathrm{F}_{1}-\mathrm{F}_{26}\right)$ using $\mathrm{H}_{2} \mathrm{O}$ / MeCN 7:3, 6:4, 5:5, 4:6, 3:7, 2:8, $1: 9$ and $0: 10$. Fractions $\mathrm{F}_{2}{ }_{2}$ $\mathrm{F}_{11}$ were combined and subjected to $\mathrm{RC}$ using $\mathrm{CHCl}_{3} / \mathrm{EtOAC}$ 9.5:0.5 (2 mm thickness) yielding 3 (326.7 mg). Fractions $\mathrm{F}_{14}-\mathrm{F}_{19}$ were pooled and subjected to $\mathrm{RC}$ using $\mathrm{CHCl}_{3}$ / EtOAc 9:1 ( $1 \mathrm{~mm}$ thickness) to yield 4 ( $20.6 \mathrm{mg}$ ). Compound 5 (58.1 mg) was obtained from the first RPCC $\mathrm{H}_{2} \mathrm{O} / \mathrm{MeCN} 3: 7$ from fraction $\mathrm{F}_{21}$. Fraction $\mathrm{F}_{22}-\mathrm{F}_{23}$ was subjected to $\mathrm{RC}$ using $\mathrm{CHCl}_{3}$ /acetone 9.8:0.2 ( $2 \mathrm{~mm}$ thickness) to yield 20 fractions $\left(F 4_{1}-F 4_{20}\right)$. Subfractions $F 4_{1}-F 4_{6}$ were combined and chromatographed on RC using $n$-hexane/ EtOAc/MeOH 8:1.9:0.1 ( $1 \mathrm{~mm}$ thickness) to yield 21 fractions $\left(\mathrm{FF}_{1}-\mathrm{F5}_{21}\right)$. Subfractions $\mathrm{F}_{11}-\mathrm{F5}_{15}$ were combined to obtain $1(6.0 \mathrm{mg})$. Fraction $\mathrm{F}_{4}$ from VLC was subjected to $\mathrm{CC}$ using $\mathrm{CH}_{2} \mathrm{Cl}_{2}$ /acetone 10:0, 9:1, 8:2, 7:3, $6: 4$ and $5: 5$ to yield 10 fractions $\left(\mathrm{FG}_{1}-\mathrm{FG}_{10}\right)$. Fractions $\mathrm{FG}_{1}-\mathrm{F}_{5}$ were combined and subjected to RC to obtain 7 (6.0 mg) using $\mathrm{CH}_{2} \mathrm{Cl}_{2}$ /acetone 9.8:0.2 (0.5 mm thickness).

\subsection{Antiplasmodial activity}

The antiplasmodial activity of the dichloromethane extract and the isolated compounds was determined by methods previously described by Widyawaruyanti [18]. The samples were dissolved in DMSO and kept at $-20^{\circ} \mathrm{C}$ until use. The malarial parasite Plasmodium falciparum (3D7) clone was propagated in a 24-well culture plate in the presence of $10,1,0.1,0.01$ and $0.001 \mu \mathrm{g} / \mathrm{ml}$ range of concentrations of each compound. Chloroquine diphosphate was used as positive control. The growth of the parasite was monitored by making a blood smear fixed with $\mathrm{MeOH}$ and stained with Geimsa (Merck). The antiplasmodial activity of each compound was expressed as an $\mathrm{IC}_{50}$ value, defined as the concentration of the compound causing 50\% inhibition of parasite growth relative to an untreated control.

\subsection{Cytotoxicity assay}

Cytotoxicity was quantitatively estimated by nonradioactive, colorimetric assay system using tetrazolium salt, MTT (Sigma, USA) as reported by Mosmann [19]. MTT was dissolved in phosphate buffered saline at $5 \mathrm{mg} / \mathrm{ml}$ and filter sterilized to eliminate a small quantity of insoluble residue present in some batches of MTT. The MTT stock solution was added directly to all appropriate microtitreplate well ( 20 per $100 \mu \mathrm{l}$ medium) containing cells. The plate was incubated for $4 \mathrm{~h}$ at $37^{\circ} \mathrm{C}$ to allow MTT metabolism to formazan. The supernatant was aspired and $100 \mu$ of acidisopropanol $(0.04 \mathrm{M} \mathrm{HCl}$ in propan-2-ol) was added and mixed thoroughly to dissolve the dark blue formazan crystals. The optical density (OD) was measured on an automated spectrophotometric EL 340 multiplet/microelisa reader (Bio-Tek Instruments Inc.) using test and reference wavelength of 570 and $630 \mathrm{~nm}$ respectively. The cytotoxic dose that killed cell was determined from the compound's concentration that reduces the mean absorbance at $570 \mathrm{~nm}$ to $5 \mathrm{C} \%\left(\mathrm{IC}_{50}\right)$ of those in the untreated control cells [20].

Malaysianone A (1): Pale yellow amorphous solid; m.p. 92; $[\alpha]_{\mathrm{D}}^{25}+24.6\left(\mathrm{c} 0.92, \mathrm{CHCl}_{3}\right) ; \mathrm{UV}(\mathrm{MeOH}) \lambda_{\max } \mathrm{nm}(\log \varepsilon)$ : 226 (4.82), 272 (4.45) and 285 (4.46); IR $v_{\max } \mathrm{cm}^{-1}(\mathrm{KBr})$ : $3365,2945,2830,1688$ and 1451; ${ }^{1} \mathrm{HNMR}\left(\mathrm{CDCl}_{3}\right)$ see Table $1 ;{ }^{13} \mathrm{C}$ NMR $\left(\mathrm{CDCl}_{3}\right)$ see Table 1 ; and HRESI-MS $\mathrm{m} / z$ : $[\mathrm{M}+\mathrm{H}]^{+} 422.4424$ (calc. for $\mathrm{C}_{25} \mathrm{H}_{26} \mathrm{O}_{6}$ 422.4444). $\mathrm{CD}$ $(c=0.125 \mathrm{mM}, \mathrm{MeOH}): 232[\Delta \varepsilon=+8.3], 252[+1.3], 255$ $[+1.6], 273[-0.1], 291[-2.0], 307[0], 313[+0.2], 316$

Table 1

${ }^{1}$ H NMR spectroscopy data of $\mathbf{1}$.

\begin{tabular}{|c|c|c|c|}
\hline No & $\delta_{\mathrm{H}}(J$ in $\mathrm{Hz})$ & $\delta_{c}$ & $\mathrm{HMBC}\left({ }^{1} \mathrm{H} \leftrightarrow{ }^{13} \mathrm{C}\right)$ \\
\hline 2 & $5.52, d d,(J=3.0 \mathrm{~Hz}, 13.2 \mathrm{~Hz})$ & 76.2 & $C-4$ \\
\hline 3 & $\begin{array}{l}3.16, d d, U=13.2,17.1 \mathrm{~Hz}, \mathrm{H}-3 \mathrm{a}) \\
2.74, d d,(J=3.0,17.1 \mathrm{~Hz}, \mathrm{H}-3 \mathrm{~b})\end{array}$ & 42.4 & $\begin{array}{l}C-2, C-4 \\
C-4\end{array}$ \\
\hline 4 & - & 196.2 & - \\
\hline 5 & $12.07(-\mathrm{OH}, \mathrm{s})$ & 164.4 & $C-5, C-6, C-8$ \\
\hline 6 & $6.01, d,\left(J_{m}=2.1 \mathrm{~Hz}\right)$ & 95.5 & $\mathrm{C}-10$ \\
\hline 7 & - & 164.9 & - \\
\hline 8 & $6.01, d,\left(U_{m}=2.1 \mathrm{~Hz}\right)$ & 96.8 & $C-6, C-7$ \\
\hline 9 & - & 163.3 & - \\
\hline 10 & - & 103.1 & - \\
\hline $1^{\prime}$ & - & 124.7 & - \\
\hline $2^{\prime}$ & - & 118.9 & - \\
\hline $3^{\prime}$ & - & 139.7 & - \\
\hline $4^{\prime}$ & - & 145.1 & - \\
\hline $5^{\prime}$ & $6.93, d,\left(J_{0}=8.4 \mathrm{~Hz}\right)$ & 114.6 & $\mathrm{C}-1^{\prime}, \mathrm{C}-3^{\prime}$ \\
\hline $6^{\prime}$ & $6.86, d,\left(J_{0}=8.4 \mathrm{~Hz}\right)$ & 118.8 & $C-2, C-2^{\prime}, C-4^{\prime}$ \\
\hline $1^{\prime \prime}$ & $5.71, d,(J=9.9 \mathrm{~Hz})$ & 118.8 & $C-1^{\prime}, C-2^{\prime}, C-3^{\prime}, C-3^{\prime \prime}$ \\
\hline $2^{\prime \prime}$ & $6.63, d,(J=9.9 \mathrm{~Hz})$ & 130.9 & $C-2^{\prime}, C-3^{\prime \prime}, C-4^{\prime \prime}, C-5^{\prime \prime}$ \\
\hline $3^{\prime \prime}$ & - & 79.1 & - \\
\hline $4^{\prime \prime}$ & $1.44, d$ & 26.1 & $C-2^{\prime \prime}, C-3^{\prime \prime}, C-5^{\prime \prime}$ \\
\hline $5^{\prime \prime}$ & $1.77, \mathrm{~m}$ & 40.7 & $C-3^{\prime \prime}, C-7^{\prime \prime}, C-8^{\prime \prime}$ \\
\hline $6^{\prime \prime}$ & $2.11, m$ & 22.8 & - \\
\hline $7^{\prime \prime}$ & $5.11, d t, U=1.2,5.7 \mathrm{~Hz})$ & 123.7 & - \\
\hline $8^{\prime \prime}$ & - & 132.1 & - \\
\hline $9^{\prime \prime}$ & $1.60, s$ & 17.7 & $\mathrm{C}-10^{\prime \prime}$ \\
\hline $10^{\prime \prime}$ & $1.69, s$ & 25.7 & $C-9^{\prime \prime}, C-8^{\prime \prime}, C-7^{\prime \prime}$ \\
\hline
\end{tabular}

Measured in $\mathrm{CDCl}_{3}$ at $300 \mathrm{MHz}\left({ }^{1} \mathrm{H}\right)$ and $75 \mathrm{MHz}\left({ }^{13} \mathrm{C}\right)$. 
$[+0.1], 330[+0.7], 338[+0.6], 355[0], 360[0.3]$ and 365 $[-0.1] \mathrm{nm}$.

\section{Results and discussion}

The chloroform extract of the inflorescences of $M$. triloba was fractionated using vacuum liquid chromatography (VLC) and purified by various chromatographic techniques. Seven compounds (1-7) were isolated (Fig. 1), including a new flavanone named malaysianone $A(\mathbf{1})$. The structural elucidation was achieved through chemical and spectroscopic analysis, including HRMS, UV, ${ }^{1} \mathrm{H},{ }^{13} \mathrm{C}$ and $2 \mathrm{D}$ NMR (COSY, $\mathrm{HMQC}$ and $\mathrm{HMBC}$ ), and by comparison with reported data.

Compound 1 was obtained as a pale yellow amorphous solid. The UV spectrum showed maxima at 232 and $329 \mathrm{~nm}$, suggestive of a flavanone moiety [21]. The IR spectrum displayed strong bands for hydroxyl $\left(3365 \mathrm{~cm}^{-1}\right)$, conjugated carbonyl $\left(1688 \mathrm{~cm}^{-1}\right)$, and alkene $\left(1451 \mathrm{~cm}^{-1}\right)$ groups. The HREIMS mass spectrum revealed a $\left[\mathrm{M}+\mathrm{H}^{+}\right.$ion at $\mathrm{m} / \mathrm{z}$ 422.4424 corresponding to the molecular formula $\mathrm{C}_{25} \mathrm{H}_{26} \mathrm{O}_{6}$. The ${ }^{1} \mathrm{H}$ NMR spectrum (Table 1 ), recorded in $\mathrm{CDCl}_{3}$, displayed a set of signals at $\delta_{\mathrm{H}} 5.52\left({ }^{1} \mathrm{H}, \mathrm{dd}, J=13.2,3.0 \mathrm{~Hz}\right), 2.74\left({ }^{1} \mathrm{H}\right.$, $d d, J=17.1,3.0 \mathrm{~Hz})$, and $3.16\left({ }^{1} \mathrm{H}, d d, J=17.1,13.2 \mathrm{~Hz}\right)$, diagnostic for $\mathrm{H}-2$ and $\mathrm{H}-3$ of a flavanone nucleus and a oneproton signal at $\delta_{\mathrm{H}} 12.07$ characteristic of the $5-\mathrm{OH}$. A doublet at $\delta_{\mathrm{H}} 6.01\left(\mathrm{~J}_{m}=2.1 \mathrm{~Hz}\right)$ was assigned to a pair of metacoupled protons at $\mathrm{H}-6$ and $\mathrm{H}-8$ of ring $\mathrm{A}$. Ortho-coupled protons at $\delta_{\mathrm{H}} 6.86$ and $6.93\left(d, J_{0}=8.4 \mathrm{~Hz}\right.$ each) were attributed to $\mathrm{H}-\mathrm{G}^{\prime}$ and $\mathrm{H}-5^{\prime}$ of the $\mathrm{B}$ ring. The presence of a pair of olefinic protons at $\delta_{\mathrm{H}} 5.71$ and $6.63(d, J=9.9 \mathrm{~Hz}$ each) indicated that an oxygen atom at $\mathrm{C}-3^{\prime}$ was cyclized with $\mathrm{C}-3^{\prime \prime}$ to form a pyran ring. Comparison with tanariflavanone $B(8)$ [22] confirmed this observation. The remaining signals were ascribed to the aliphatic protons of the pyran and prenyl groups $\left[\delta_{\mathrm{H}} 1.44\left(\mathrm{H}-4^{\prime \prime}\right), \delta_{\mathrm{H}} 1.77\left(\mathrm{H}-5^{\prime \prime}\right), \delta_{\mathrm{H}} 2.11\left(\mathrm{H}-6^{\prime \prime}\right), \delta_{\mathrm{H}} 5.11\right.$ $\left(\mathrm{H}-7^{\prime \prime}\right), \delta_{\mathrm{H}} 1.60\left(\mathrm{H}-9^{\prime \prime}\right)$ and $\left.\delta_{\mathrm{H}} 1.69\left(\mathrm{H}-10^{\prime \prime}\right)\right]$. The ${ }^{13} \mathrm{C} \mathrm{NMR}$ spectrum of 1 showed 25 carbon resonances (Table 1) including a downfield carbonyl signal at $\delta_{c} 196.2$ (C-4). Five oxyaryl carbons can be observed at $\delta_{c} 139.7,145.1,163.3$, 164.4 , and 164.9 , four quaternary $\mathrm{sp}^{2}$ carbons at $\delta_{c} 103.1$, $118.9,124.7$ and 132.1 , and seven methine $\mathrm{sp}^{2}$ carbons at $\delta_{\mathrm{C}}$ 95.5, 96.8, 114.6, $118.8(2 \mathrm{C}), 123.7$ and 130.9. The flavanone

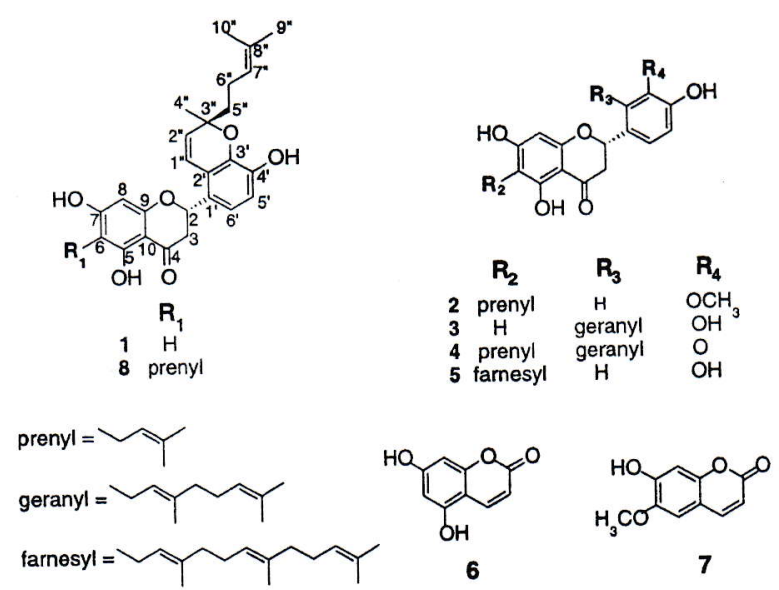

Fig. 1. Chemical constituents from the inflorescences of Macaranga triloba. nucleus was evidenced from the $\mathrm{sp}^{3}$ methylene and methine carbons at $\delta_{c} 42.4$ and 76.2 , respectively. The rest of the signals were accounted for six aliphatic carbons in the pyran and prenyl groups $\left(\delta_{c} 17.7,22.8,25.7,26.1,40.7\right.$ and 79.1).

The HMBC correlations of 1 are illustrated in Fig. 2 and tabulated in Table 1. The correlations between $\delta_{H} 6.93$ with quaternary $\mathrm{sp}^{2}$ carbon $\delta_{\mathrm{c}} 124.7$ and oxyaryl $\mathrm{sp}^{2}$ carbon at $\delta_{\mathrm{C}}$ 139.7 together with correlations showed by proton $\delta_{H} 6.86$ with another oxyaryl $\mathrm{sp}^{2}$ carbon at $\delta_{\mathrm{C}} 145.1$ confirmed the location of $\delta_{\mathrm{H}} 6.93$ and 6.86 at $\mathrm{H}-5^{\prime}$ and $\mathrm{H}-\mathrm{6}^{\prime}$ of the B-ring, respectively. The olefinic proton at $\delta_{\mathrm{H}} 5.71$ gave ${ }^{3} \mathrm{~J} \mathrm{HMBC}$ correlations to $\delta_{c} 124.7\left(\mathrm{C}-1^{\prime}\right)$ and quaternary $\mathrm{sp}^{3}$ carbon $\delta_{c}$ 79.1 , thus supporting its position at $\mathrm{H}-1^{\prime \prime}$ while its COSY correlation with $\delta_{\mathrm{H}} 6.63$ established $\mathrm{H}-2^{\prime \prime}$. The ${ }^{2} J$ and ${ }^{3} J \mathrm{HMBC}$ correlations observed between the methyl proton at $\delta_{\mathrm{H}} 1.44$ with methine $\mathrm{sp}^{2}$ carbon $\delta_{c} 130.9\left(\mathrm{C}-2^{\prime \prime}\right), \delta_{c} 79.1\left(\mathrm{C}-3^{\prime \prime}\right)$ and methylene $\mathrm{sp}^{3}$ carbon $\delta_{C} 40.7\left(C-5^{\prime \prime}\right)$ indicated the methyl attachment to the pyran ring. Another set of HMBC correlations between the methylene protons at $\delta_{\mathrm{H}} 1.77$ with $\delta_{\mathrm{C}} 79.1\left(\mathrm{C}-3^{\prime \prime}\right)$ and methine $\mathrm{sp}^{2}$ carbon $\delta_{c} 123.7$ supported its connectivity to the pyran and prenyl groups. Compound 1 has a positive Cotton effect at $338 \mathrm{~nm}(\Delta \varepsilon+0.6)$ and a negative Cotton effect at $291 \mathrm{~nm}(\Delta \varepsilon-2.0)$, thus confirming the stereochemistry of C-2 as $S$ [23]. The distinct negative Cotton effect at $273 \mathrm{~nm}$ $(\Delta \varepsilon-0.1)$ enabled the assignment of the absolute stereochemistry of $C-3^{\prime \prime}$ as $R$. The structure of 1 was thus assigned as shown in Fig. 1. Based on these assignments, this new flavanone was established as malaysianone $A$.

Six other known compounds were identified as 6-prenyl-3'methoxyeriodictyol (2) [24], nymphaeol B (3) [25], nymphaeol C (4) $[26,27], 6$-farnesyl-3', $4^{\prime}, 5,7$-tetrahydroxyflavanone (5) [28], 5,7-dihydroxycoumarin (6) [29] and scopoletin (7) [30]. Compounds 2,5 , and 6 were found for the first time in the genus Macaranga.

Prenylated and geranylated flavanones have been reported to possess several biological activities. In this study, four major flavonoids (2-5) were subjected to antiplasmodial and cytotoxicity activities. Biological activity of 1 cannot be tested as it was obtained in small amounts. The dichloromethane crude extract of $M$. triloba was tested for its in vitro antiplasmodial activity against a chloroquine sensitive strain of P. falciparum

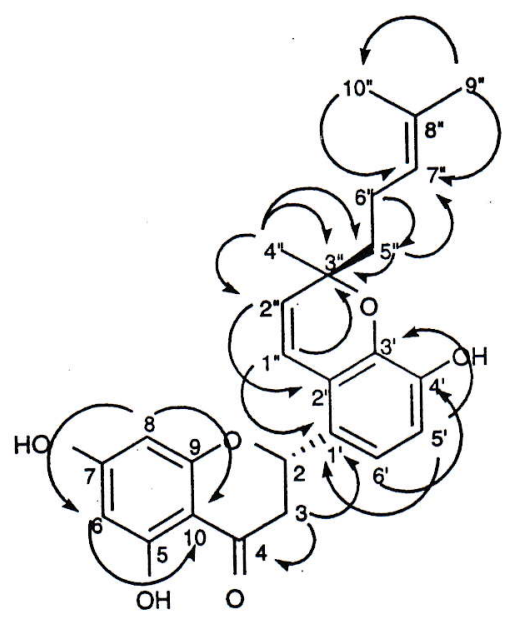

Fig. 2. Representative HMBC correlations for 1. 
Table 2

Antimalarial activity of flavonoids of $M$. triloba.

\begin{tabular}{ll}
\hline Compounds & $\mathrm{IC}_{50}(\mu \mathrm{M})$ \\
\hline 2 & n.a. \\
3 & $4.02 \pm 0.9$ \\
4 & $2.04 \pm 0.6$ \\
5 & $0.06 \pm 0.8$ \\
Chloroquine diphosphate & $0.0063 \pm 0.5$ \\
\hline
\end{tabular}

Each sample was tested in triplicates; the $I_{50}$ values were obtained from the average values of percent inhibition within a series of concentration; n.a. - no activity.

(3D7). The $I C_{50}$ value of the crude extract $\left(I C_{50}=2.01 \mu \mathrm{g} / \mathrm{ml}\right)$ showed a concentration-dependent growth inhibition of the parasite $P$. falciparum, indicating the crude extract as a good potential as an antiplasmodial agent. Subsequently, the flavonoids isolated from the inflorescences of $M$. triloba were screened for their antiplasmodial activity (Table 2). Compound 5 displayed strong antiplasmodial activity with an $\mathrm{IC}_{50}$ value of $0.06 \mu \mathrm{M}$, followed by a moderate activity of 4 and 3 with IC S0 $_{50}$ 2.04 and $4.02 \mu \mathrm{M}$, respectively. Compound 2 however, showed no activity towards the $P$. falciparum strain. The presence of adjacent methoxyl and hydroxyl groups [31] or the absence of adjacent hydroxyl groups might contribute to the inactivity of compound 2 . The substituents on the flavanone skeleton clearly influenced its antiplasmodial activity which warrants further investigation.

The flavonoids were tested for cytotoxic activity against three cancer cell lines, namely HL-60 (human leukemia), MCF-7 (human breast cancer), and HeLa (human cervical cancer), using 3-[4,5-dimethylthiazol-2-yl]-2,5-diphenyl tetrazolium bromide (MTT) dye-reduction assay (Table 3). Compound 5 exhibited very strong activity against $\mathrm{HeLa}, \mathrm{HL}-60$ (IC $_{50}$ values of $1.3,3.3$ respectively) and strong inhibition against MCF-7 cells with $\mathrm{IC}_{50}$ value $5.6 \mu \mathrm{g} / \mathrm{ml}$. Compounds 2,3 and 4 demonstrated moderate activity with $\mathrm{IC}_{50}$ of $12.2,17.0$ and $18.2 \mu \mathrm{g} / \mathrm{ml}$, respectively against HeLa cell lines and weak activity towards MCF-7 with $\mathrm{IC}_{50} 22.8,23.5$ and $23.0 \mu \mathrm{g} / \mathrm{ml}$, respectively. Compounds 2 and 4 were moderately active against HL-60 cell lines with $\mathrm{IC}_{50}$ value of 15.1 and $11.6 \mu \mathrm{g} / \mathrm{ml}$, respectively, while 3 weakly inhibited the growth of $\mathrm{HL}-60$ cell line with $\mathrm{IC}_{50} 21.3 \mu \mathrm{g} /$ $\mathrm{ml}$. Based on the observation displayed on the activity of compounds 2-5, we expect 1 to show similar biological activity as 3. This is due to the similar structural property of $\mathbf{1}$ and $\mathbf{3}$. Compound 5 which contained the farnesyl group located at C-6 was found to display strong antiplasmodial and cytotoxic activities. However, macagigantin, a farnesylated flavonol from $M$. gigantea merely showed moderate activity against P-388 cells ( $\mathrm{IC}_{50}$ value of $11.3 \mu \mathrm{M}$ ) [32]. This compound does not possess the adjacent hydroxyl groups on ring B as compound 5 . This difference may contribute to the stronger activity displayed by compound $\mathbf{5}$. We can conclude that the structural criteria reported in this study, showed the importance of the presence of farnesyl (on ring A) and adjacent hydroxyl groups (on ring B) on the biological activity of flavonoids.

\section{Acknowledgments}

The authors would like to thank the Faculty of Applied Sciences, Universiti Teknologi MARA for financing this research project and the National Science Fellowship (NSF) of the
Table 3

Cytotoxic activity of flavonoids of $M$. triloba.

\begin{tabular}{lrrr}
\hline Cell lines & \multicolumn{4}{l}{$\mathrm{IC}$ 50 value $(\mu \mathrm{g} / \mathrm{ml})$} & \multicolumn{1}{l}{ HeLa } \\
\cline { 2 - 4 } & HL-60 & \multicolumn{1}{l}{ MCF-7 } & $12.2 \pm 2.6$ \\
\hline 2 & $15.1 \pm 3.5$ & $22.8 \pm 0.8$ & $17.0 \pm 2.8$ \\
3 & $21.3 \pm 3.2$ & $23.5 \pm 3.6$ & $18.2 \pm 1.0$ \\
4 & $11.6 \pm 1.5$ & $23.0 \pm 2.4$ & $1.3 \pm 0.8$ \\
\hline
\end{tabular}

$\mathrm{IC}_{50}$ activity (inhibition): very strong: $<5 \mu \mathrm{g} / \mathrm{ml}$; strong: $<5-10 \mu \mathrm{g} / \mathrm{ml}$; moderate: $10-20 \mu \mathrm{g} / \mathrm{ml}$; weak: $20-100 \mu \mathrm{g} / \mathrm{ml}$ and not active $>100 \mu \mathrm{g} / \mathrm{ml}$.

Ministry of Science, Technology and Innovation, Malaysia (MOSTI) for financing the scholarship of one of the authors.

\section{References}

[1] Beutler JA, McCall KL, Boyd MR. A novel geranylflavone from Macaranga schweinfurthii. Nat Prod Lett 1999;13:29-32.

[2] Lim TY, Lim YY, Yule CM. Evaluation of antioxidant, antibacterial and anti tyrosinase activities of four Macaranga species. Food Chem 2009;114:594-9.

[3] Sutthivaiyakit S, Unganont S, Sutthivaiyakit P, Suksamrarn A. Diterprenylated and prenylated flavonoids from Macaranga denticulata. Tetrahedron 2002;58:3619-22.

[4] Jang DS, Cuendet M, Hawthorne ME, Kardono LBS, Kawanishi K, Fong HHS, et al. Prenylated flavonoids of the leaves of Macaranga conifera with inhibitory activity against cyclooxygenase-2. Phytochemistry 2002;61:867-72.

[5] Schutz BA, Wright AD, Rali T, Sticher O. Prenylated flavanones from the leaves of Macaranga pleiostemona. Phytochemistry 1995;40:1273-7.

[6] Kumazawa S, Nakayama, Shimoi K, Goto T, Fukumoto S, Arakaki T. Flavanone compound and uses thereof. United States Patent, US $7,256,214$ B2, 2007.

[7] Beutler JA, Shoemaker RH, Johnson T, Boyd MR. Cytotoxic geranyl stilbenes from Macaranga schweinfurthii. J Nat Prod 1998:61:1509-12.

[8] Beutler JA, Jato J, Cragg GM, Boyd MR, Schweinfurthin D. A cytotoxic stilbene from Macaranga schweinfurthii. Nat Prod Lett 2000;14: $399-404$.

[9] Li X, Xu L, Wu P, Xie H, Huang Z, Ye W, et al. Prenylflavonols from the leaves of Macaranga sampsonii. Chem Pharm Bull (Tokyo) 2009;57: 495-8.

[10] Corner EJH. Wayside trees of Malaya, vol. 2. Kuala Lumpur: United Selangor Press; 1988.

[11] Fiala B, Maschwitz U. Studies on the South East Asian ant-plant association Crematogaster bomeensis/Macaranga: adaptations of the ant partner. Insect Soc 1990;37:212-31.

[12] Fiala B, Maschwitz U, Tho YP, Helbig AJ. Studies of a South East Asian ant-plant association: protection of Macaranga trees by Crematogaster bormeensis. Oecologia 1989;79:463-70.

[13] Siregar M, Sambas EN. Floristic composition of peat swamp forest in Mensemat-Sambas, West Kalimantan. Proc. Internatl. Symp. Tropic. Peatlands, 3; 2000. p. 153-64.

[14] Dinh V, Zhang HP, Duc NM, Tuu NV, Qin GW. A new geranyl flavanone from Macaranga triloba. J Asian Nat Prod Res 2006;8:155-8.

[15] Sultana S, llyas M. Chromenoflavones from Macaranga indica. Phytochemistry 1986;25:953-4.

[16] Yoder BJ, Cao S, Norris AJ, Miller JS, Ratovoson F, Razafitsalama J, et al. Cytotoxic prenylated stilbenes and flavonoids from Macaranga alnifolia from the Madagascar rainforest. J Nat Prod 2007;70:342-6.

[17] Tseng MH, Chou CH, Chen YM, Kuo YH. Alleopathic prenylflavanones from the fallen leaves of Macaranga tanarius.J Nat Prod 2001;64:827-8.

[18] Widyawaruyanti A, Subehan, Kalauni SK, Awale S, Nindatu M, Zaini NC, et al. New prenylated flavones from Artocarpus champeden and their antimalarial activity in vitro. J Nat Med 2007;61:410-3.

[19] Mosmann T. Rapid colorimetric assay for cellular growth and survival: application to proliferation and cytotoxicity assays. J Immunol Methods 1983;65:55-63.

[20] Ghani NA Ahmat N, Ismail NH, Zakaria I, Zawawi NKNA. Chemical constituents and cytotoxic activity of Polyalthia cauliflora var. cauliflora. Res J Med Plant 2011;6:74-82.

[21] Markham KR. Techniques of flavonoid identification. London: Academic Press Inc; 1982

[22] Tseng MH, Kuo YH, Chen YC, Chou CH. Allelopathic potential of Macaranga tanarius (L) Muell.-Arg. J Chem Ecol 2003;29:1269-86. 
[23] Kawakami S Harinantenaina L Matsunami K, Otsuka H, Shinzato T, Takeda $Y$ Macaflavanones $A-G$, prenylated flavanones from the leaves of Macaranga tanarius. J Nat Prod 2008;71:1872-6.

[24] Wollenweber E, Roitman JN. New reports on surface flavonoids from Chameebatioria (Rosaceae), Dodonaea (Sapindaceae), Elsholtria (Lamiaceae), and Silphium (Asteraceae). Nat Prod Commun 2007;2:385-9.

ceae), and Silphium (Asteraceae). Nat Proi N, Ruchirawat S, Sutthivaiyakit S.

[25] Phommart S, Sutthivaiyakit P, Chimnoi N, Ruchirawat S, Sutthivalyak Constituents of the leaves of Macaranga tanarius. J Nat Prod 2005:68:
$927-30$.

[26] Kumazawa S, Goto H, Hamasaka T, Fukumoto S, Fujimoto T, Nakayama $T$. A new prenylated flavonoid from Propolis collected in Okinawa Japan. Biosci Biotechnol Biochem 2004;68:260-2.

[27] Yakushijin K, Shibayama K, Murata H, Furukawa H. New prenylflavanones from Hernandia nymphaefolia (Presl.) Kubitzki. Heterocycles 1980;14:397-402.
[28] Ahsan M, Gray AI, Waterman G, Armstrong JA. Farnesyl acetophenone and flavanone compounds from the aerial parts of Boronia ramosa.J Nat Prod 1994;57:673-6.

[29] Batsuren Batirov EKH, Malikov VM. Coumarins of Haplophyllum dauricum. 5,7-Dihydroxycoumarin and its C-glucoside. Chem Nat Compounds 1982;18:616-7.

30) Farid HAR, Kunert O, Haslinger E, Seger C. Elucidation of iridoide and coumarin derivatives from Xeromphis nilotica (Rubiaceae). Monatsh Chem 2002:133:1453-8.

[31] Osman CP, Ismail NH, Ahmad $R$, Ahmat $N$, Awang $K$, Jaafar FM Osman CP, Ismail NH, Ahmesthodial activity from the roots of Rennelia Anthraquinones with antiplasmodial activity from the 26.

(32) Tanjung M Hakim EH, Mujahidin D, Hanafi M, Yana MS. Macagigantin, a farnesylated flavonol from Macaranga gigantean. J Asian Nat Prod Res 2009;11:929-32. 


\section{Editor-in-Chief:}

Prof. Giovanni Appendino, Faculty of Pharmacy, University of Eastern Piedmont Largo Donegani, 2

28100 Novara, Italy

\section{Editorial Board Members:}

Y. Asakawa (Tokushima Bunri University, Japan) E. Bombardelli (Indena SpA, Milan, Italy)

J.B. Calixto (Universidade Federal de Santa Catarina, Florianopolis, Brazil)

E.M. Croom, Jr. (Oxford, Mississippi, USA)

B. Danieli (University of Milan, Italy)

G. Delgado (Universidad Nacional Autónoma de México, Coyoacán México)

R. Della Loggia (University of Trieste, Italy)

B. Gabetta (Indena SpA, Milan, Italy)

J. Gertsch (University of Bern, Switzerland)

E.L. Ghisalberti (University of Western Australia, Perth, Australia)

S. Gibbons (University of London, UK)

D.-A. Guo (Chinese Academy of Science, Shanghai, China)

M. Hamburger (University of Basel, Switzerland)

A. Hensel (University of Münster, Germany)

$\mathrm{K}$. Hostettmann (Universite de Lausanne, Switzerland)
P.J. Houghton (King's College London, UK)

A.D. Kinghorn (Ohio State University, Columbus, Ohio, USA)

V. Lanzotti (University of Molise, Italy)

$\mathrm{S}$. Malandrino (Indena SpA, Milan, Italy)

E. Munoz (University of Cordoba, Spain)

U. Nyman (Swedish Seed Testing \& Certification Institute, Svalov, Sweden)

G. Pauli (University of Illinois at Chicago, USA)

J.M. Pezzuto (University of Hawaii, Hilo, Hawaii)

P. Rosoanaivo (IMRA; Antanaraivo, Madagascar)

O. Sterner (University of Lund, Sweden)

H.-D. Sun (Kuming Institute of Botany, Yunnan, P.R. of China)

C. Tamayo (Bethesda, MA, USA)

L. Verotta (University of Milano, Italy)

$\mathrm{R}$. Verpoorte (University of Leiden, Leiden, The Netherlands)

A.J. Vlietinck (Universiteit Antwerpen, Belgium)

O. Werz (Friedrich-Schiller-University, Jena, Germany) 


\section{Fitoterapia}

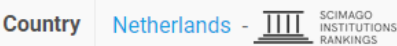

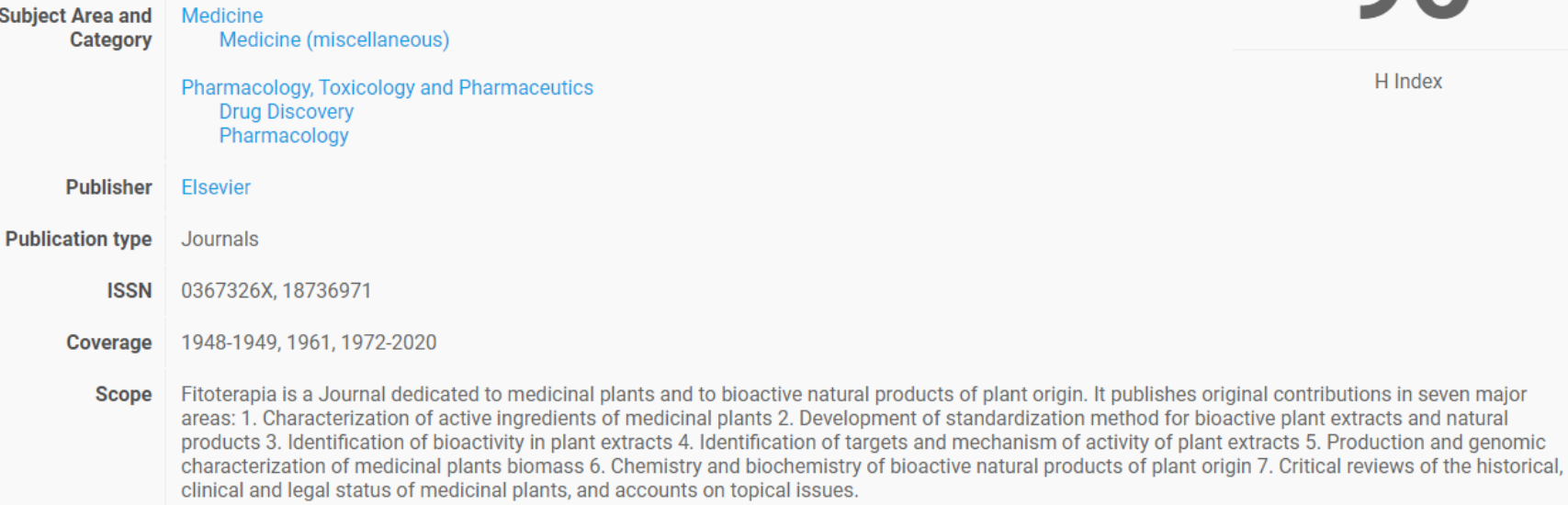

Scope Fitoterapia is a Journal dedicated to medicinal plants and to bioactive natural products of plant origin. It publishes original contributions in seven majo areas: 1 . Characterization of active ingredients of medicinal plants 2 . Development of standardization method for bioactive plant extracts and natural products 3 . Identification of bioactivity in plant extracts 4 . Identification of targets and mechanism of activity of plant extracts 5 . Production and genomic characterization of medicinal plants biomass 6 . Chemistry and biochemistry of bioactive natural products of plant origin 7 . Critical reviews of the historical, clinical and legal status of medicinal plants, and accounts on topical issues.
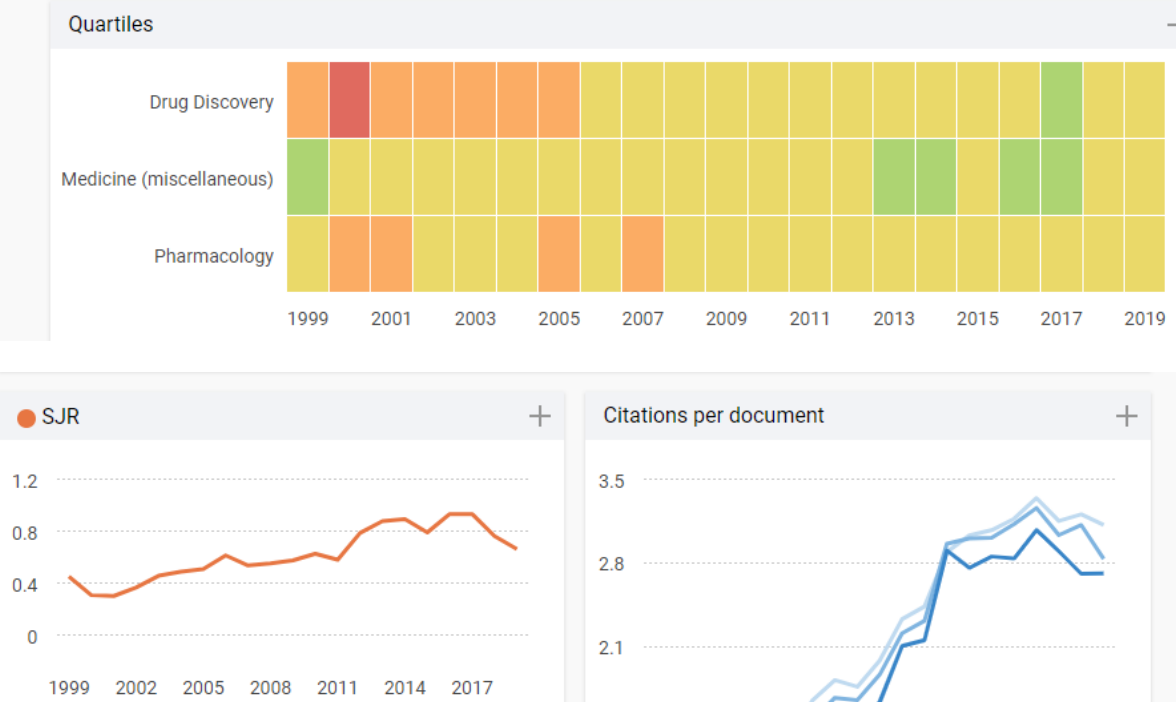

\section{Total Cites Self-Cites}

$4 \mathrm{k}$

$2 \mathrm{k}$

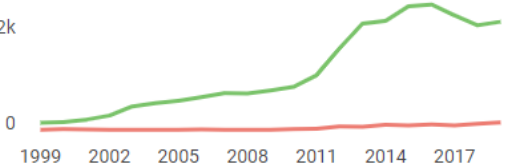

$\begin{array}{lllllll}1999 & 2002 & 2005 & 2008 & 2011 & 2014 & 2017\end{array}$
$+$

$+$

0.7

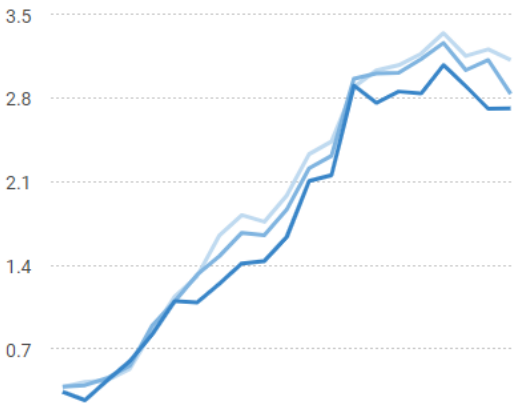

$1999 \quad 2002 \quad 2005 \quad 2008 \quad 2011 \quad 2014 \quad 2017$

Cites / Doc. (4 years)

Cites / Doc. (3 years)

Cites / Doc. (2 years)

96

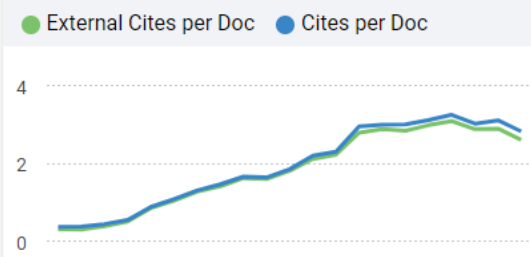

$\begin{array}{lllllll}1999 & 2002 & 2005 & 2008 & 2011 & 2014 & 2017\end{array}$
$+\%$ International Collaboration $\quad+$

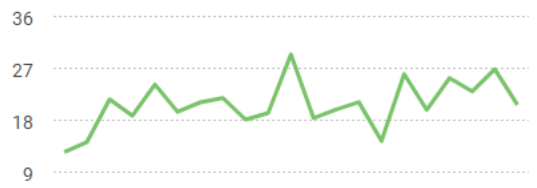

$\begin{array}{lllllll}1999 & 2002 & 2005 & 2008 & 2011 & 2014 & 2017\end{array}$

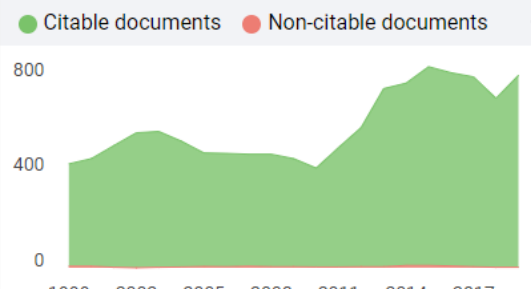

$\begin{array}{lllllll}1999 & 2002 & 2005 & 2008 & 2011 & 2014 & 2017\end{array}$

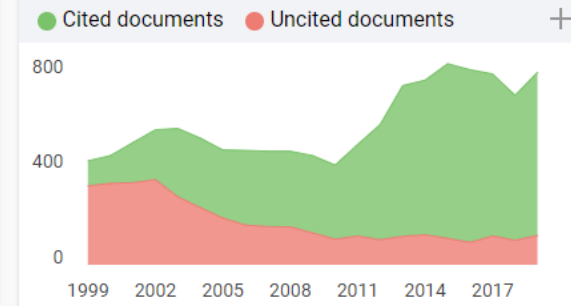

Fitoterapia

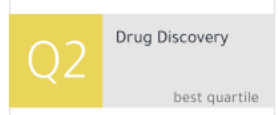

SJR 2019

0.67

powered by scimagojr.con $\leftarrow$ Show this widget in your own website

Just copy the code below and paste within your $\mathrm{html}$ code:

<a href="https://www.scima! 